\title{
MOLECULAR CHARACTERIZATION OF ANTIBACTERIAL RESISTANCE GENES OF SALMONELLA IN DUCKS
}

\author{
ZEINAB KHALIFA MOSTAFA KHALIFA ${ }^{1}$; AWAD ABD EL-HAFEZ IBRAHIM ${ }^{2}$; \\ TOLBA YOUNES ABD EL-MOTELIB ${ }^{2}$ AND \\ AZHAR MOHAMED ABD EL-AZIZ ${ }^{1}$ \\ ${ }^{1}$ Assistant Researcher of Poultry Diseases Department, Animal Health Research Institute, Assiut \\ Branch, Egypt. \\ ${ }^{2}$ Avian and Rabbit Diseases Department, Faculty of Veterinary Medicine, Assiut University,
} Egypt.

Received: 5 September 2021; Accepted: 30 September 2021

\begin{abstract}
Due to financial losses associated with avian salmonellosis, high costs of prohibiting its spread and prevention and its multiple drug resistance, Salmonella infection, particularly in ducks, attracted interest of many researchers as duck is a main reservoir of salmonella transmitted to human. Therefore, this study aimed at identifying circulating salmonella of ducks in Assiut governorate and assessing their antimicrobial susceptibility profile. Five hundred and sixty samples (150 livers and 410 cloacal swabs) of infected, freshly dead and apparently healthy ducks, were obtained from different farms in Assiut governorate for bacteriological, serological and molecular examination. An overall 16.6\% Salmonella detection rate was recorded, where 15 isolates were identified serologically and molecularly as S. typhimurium $(93.3 \%)$ and S. infantis $(6.7 \%)$. Basing on antibiogram guidelines, detected Salmonella isolates were completely resistant (100\%) to cephradine and amoxicillin, but had variable resistance degrees to colistin sulfate $(80 \%)$, streptomycin (60\%), chloramphenicol (33.3\%), ampicillin and neomycin (26.7\% of each). MIC test presented that all isolates were absolutely sensitive to colistin and doxycycline, but completely resistant to sulfaquinoxaline. High resistance rates occurred to cephradine, amoxicillin, streptomycin and florfenicol. sul-1, strA-strB, bla TEM, aadA and floR antibacterial resistance genes were assigned in variable frequencies $(100 \%, 73.3 \%, 73.3 \%$, $66.7 \%$ and $46.7 \%$, respectively). In conclusion, S. typhimurium and S. infantis serovars are circulating among duck farms in Assiut. These serotypes exhibited genetic multiple drug resistance, that require special strict biosecurity and searching alternative effective control strategies.
\end{abstract}

Keywords: Ducks, Salmonella, PCR, MIC, Resistance gene.

Corresponding author: Zeinab Khalifa Mostafa Khalifa

E-mail address: vet.zeinab@gmail.com

Present address: Assistant Researcher of Poultry Diseases Department, Animal Health Research Institute, Assiut Branch, Egypt 


\section{INTRODUCTION}

Having unique characters over other poultry types, duck industry forms important part of poultry sector worldwide either rural or enterprises. For many years, Salmonella infection was concerned researchers, veterinarians, and public health authorities due to its associated losses in livestock and risks of food poisoning, rank number one among the potentially foodborne bacteria. In spite exerted efforts and advances in prevention and control measures Salmonella infection still induce great economic losses. Being the most important reservoir of Salmonellae transmissible to human, duck received great interest among researchers (Yang et al., 2019). Salmonella infected birds show non-specific signs include depression, poor growth, weakness and diarrhea. The majority of mortalities usually occur in the first weeks of life. Rapidly developed septicemia is the origin of high mortality with limited or no clinical signs (Gast, 2008). Many Salmonella serotypes were detected in ducks, most of public health significance but some, including $S$. gallinarum, $S$. pullorum, S. typhimurium, S. enteritidis and $S$. anatum caused considerable losses in birds younger than few-weeks old (Buxton, 1957). Salmonella contains sequences unique invasion (invA) gene to this genus and confirmed to be a suitable target designed for PCR with a potential diagnostic application (Jamshidi et al., 2009). Like other pathogens of clinical and economic significance, Salmonellae face the problem of drug resistance, principally multidrug resistance that must be periodically assessed and monitored. Antimicrobial resistance is a phenomenon of huge concern for Salmonella and other foodborne pathogens. The extensive and misuse of antimicrobials in veterinary medicine is regularly incriminated in transfer of antibiotic resistance to human pathogens and spreading of multiple antibiotic resistant. Moreover, World Health Organization emphasized increasing number of non-typhoid Salmonellae resistant to antibiotics (McEwen, 2012). Polymerase chain reaction (PCR) is a molecular technique took up an increasingly significant space in the field of laboratory diagnostics, allowing the detection of various pathogens and their genetic properties like antibacterial resistance genes (Santos et al., 2001). So this study aimed at molecular identification of Salmonella isolates by conventional PCR, determining antibacterial susceptibility pattern and molecular characterization of antibacterial resistance genes among prevalent Salmonella serotypes.

\section{MATERIALS AND METHODS}

\section{Sampling}

Altogether, 560 samples (150 livers and 410 cloacal swabs) of infected, freshly dead and apparently healthy ducks, were obtained from different farms in Assiut and transported to laboratory of Faculty of Veterinary Medicine- Assiut University, Egypt.

\section{Bacteriological and biochemical examination:}

According to ISO 6579 (2002), samples were bacteriologically examined for Salmonella isolation. Briefly, swab from each sample was inoculated separately under complete aseptic conditions- into 1:10 Buffered Peptone Water (preenrichment) and incubated aerobically at $37^{\circ} \mathrm{C}$ for 18 hours. Then, $0.1 \mathrm{ml}$ from the incubated broth was transferred to $10 \mathrm{ml}$ Rappaport Vassilidis Soy (RVS) broth 
and incubated at $41.5^{\circ} \mathrm{C}$ for 24 hours. A loopful from the incubated RVS was streaked onto Xylose Lysine Deoxycholate (XLD) and incubated at $37^{\circ} \mathrm{C}$ for 24 hours. The suspected Salmonella colonies were gram stained for cellular morphology and identified biochemically by using (urease, TSI, lysine decarboxylation, indole and citrate utilization tests).

\section{Molecular identification of Salmonella isolates:}

Biochemically suspected Salmonella colonies were molecularly ascertained according to Dashti et al. (2009) and Oliveira et al. (2002). In brief, pure colonies were suspended in $5 \mathrm{ml}$ phosphate buffered saline (PBS) and centrifuged at 3000rpm $\left(4^{\circ} \mathrm{C}\right)$ for 10 minutes (repeated thrice till obtaining pellet). Pellets washed twice with PBS, re-suspended in $100 \mu \mathrm{l}$ of degrade free water, heated for $10 \mathrm{~min}$ and chilled in ice for $30 \mathrm{~min}$. and centrifuged at $3000 \times \mathrm{g}$ for 5 min at $4^{\circ} \mathrm{C}$. finally, supernatants were taken and used as template DNA it was amplified by Polymerase Chain Reaction assay using Salmonella specific invA gene primer set:

Forward (F): (5'-GTGAAATTATCGC CACGTTCGGGCAA3 $3^{\prime}$ ) and

Reverse(R) : ( 5'TCATCGCACCGTCA AAGGAACC-3') and Go Taq ${ }^{\circledR}$ Green Master mix (Promega) in Veriti thermocycler (Applied biosystems, Germany) following Oliveira et al. (2002) cycling conditions. Accurately, an initial hot start at $94^{\circ} \mathrm{C}$ for 5 minutes, followed by 35 cycles, each consisting of $94^{\circ} \mathrm{C}$ for $30 \mathrm{~s}, 55^{\circ} \mathrm{C}$ for $30 \mathrm{~s}$, and $72^{\circ} \mathrm{C}$ for $30 \mathrm{~s}$ and the step of final extension at $72^{\circ} \mathrm{C}$ for 7 minutes. The amplified products $(5 \mu \mathrm{l})$ were identified on $1.5 \%$ agarose gel stained with ethidium bromide and visualizing them with UV light in comparison to molecular size of 100-1.500bp DNA ladder (RTU, Cat.No.DM001.R500, 11bands).
Molecular typing of Salmonella isolates:

Multiplex and conventional PCR assays were carried out using primer sets specific for $S$. typhimurium with sequences:

F1:(5'CAGCACCAGTTCCAACTTGA TAC-3').

R1:(5'GGCTTCCGGCTTTATTGGTA AGCA -3').

F2:(5'ATAGCCATCTTTACCAGTTCC CCC-3').

R2:(5'GCTGCAACTGTTACAGGATA

TGCC-3') (Lim et al., 2003) and $S$. infantis with sequence $\mathbf{F}$ : (5'AACAACGACAGCTTATGCCG-3')

and R: (5'-CGCAGCGTAAAGCAACT 3') (Kardos et al., 2007), producing amplicons with molecular weight of 663bp, 183bp and 413bp, respectively. The reaction conditions for $S$. typhimurium ( $R f b j$ and FliC genes) consisted of a primary denaturation at $95^{\circ} \mathrm{C}$ for $2 \mathrm{~min}$, followed by thirty cycles of denaturation at $95^{\circ} \mathrm{C}$ for $1 \mathrm{~min}$, annealing at $57^{\circ} \mathrm{C}$ for $1 \mathrm{~min}$ and extension at $72^{\circ} \mathrm{C}$ for $1 \mathrm{~min}$ followed by final extension at $72^{\circ} \mathrm{C}$ for $10 \mathrm{~min}$. While, the PCR reaction conditions for $S$. infantis (fljB gene) consisted of an intial denaturation at $95^{\circ} \mathrm{C}$ for 6 minutes, followed by 35 cycles of final denaturation at $95^{\circ} \mathrm{C}$ for 1 minutes, annealing at $56^{\circ} \mathrm{C}$ for 15 seconds and extension at $72^{\circ} \mathrm{C}$ for 1 minutes followed by final extension at $72^{\circ} \mathrm{C}$ for 4 minutes. PCR products were screened as previously described for invA gene PCR.

Assessing Antibacterial Susceptibility Pattern of Salmonella isolates using Disc diffusion method:

Antibacterial sensitivity of Salmonella isolates was assessed using 15 antibacterial agents. The sensitivity and the resistance were determined by criteria of Clinical and Laboratory Standard Institute (CLSI, 2018). 
Determining antibacterial Minimum Inhibitory Concentration (MIC) to Salmonella isolates: according to (Stanković et al., 2017).

Susceptibility of Salmonella to streptomycin, gentamycin, neomycin, florfenicol, sulphaquinoxalin, doxycycline, cephradine and amoxicillin was checked in microtiter plate 96 wells using double fold microdilution method against all isolated Salmonella in a density of $10^{5}$ CFU (CLSI, 2018). Each antimicrobial had a concentration of $10 \mu \mathrm{g} / \mathrm{mL}$, and $2.56 \mu \mathrm{l}$ of each antimicrobial was added into two wells in the first row of the plate, followed by 50 $\mu l$ tryptone soya broths with bacteria was added to all wells. Extra $50 \mu 1$ tryptone soya broth containing bacteria was put in to the $1^{\text {st }}$ row of plate (antimicrobials wells) then twofold serial dilution method was made and remove the last $50 \mu \mathrm{l}$. The broth containing bacterial inoculum was taken as a positive control while, broth without bacterial inoculum used as a negative control. after a 24-hours of incubation at $37^{\circ} \mathrm{C}$, the microtiter plates were examined for the lowest concentration showing no detectable growth (MIC).

\section{Molecular identification of antibacterial resistance genes among Salmonella isolates using PCR:}

Table 1: Primer's sequences and amplicon size (bp) for identification of Florfenicol, $\beta$ lactams and Sulfonamides resistance genes among Salmonella isolates.

\begin{tabular}{|c|c|c|c|c|c|}
\hline Primer & & Target & primer sequence & Amplicon size & References \\
\hline \multirow{2}{*}{ Florfenicol } & StCM-L & \multirow{2}{*}{ floR } & $\begin{array}{c}\text { CACGTTGAGCCTCTATAT } \\
\text { GG } \\
\end{array}$ & \multirow{2}{*}{ 888bp } & \multirow{2}{*}{$\begin{array}{l}\text { Ahmed } e t \\
\text { al., } 2007\end{array}$} \\
\hline & StCM-R & & $\begin{array}{c}\text { ATGCAGAAGTAGAACGC } \\
\text { GAC }\end{array}$ & & \\
\hline \multirow{2}{*}{$\beta$-lactams } & $\begin{array}{c}\text { bla } \\
\text { TEM-F }\end{array}$ & \multirow{2}{*}{$\begin{array}{l}\text { bla } \\
\text { TEM }\end{array}$} & ATCAGCAATAAACCAGC & \multirow{2}{*}{$517 \mathrm{bp}$} & \multirow{2}{*}{$\begin{array}{l}\text { Colom et } \\
\text { al., } 2003\end{array}$} \\
\hline & $\begin{array}{c}\text { bla } \\
\text { TEM-R }\end{array}$ & & CCCCGAAGAACGTTTTC & & \\
\hline \multirow{2}{*}{ Sulfonamides } & Sul 1-F & \multirow{2}{*}{ Sul 1} & $\begin{array}{c}\text { TCACCGAGGACTCCTTCT } \\
\text { TC } \\
\end{array}$ & \multirow{2}{*}{ 316bp } & \multirow{2}{*}{$\begin{array}{l}\text { Randall et } \\
\text { al., } 2004\end{array}$} \\
\hline & Sul 1-R & & $\begin{array}{l}\text { AATATCGGGATAGAGCG } \\
\text { CAG }\end{array}$ & & \\
\hline
\end{tabular}

Table 2: Showing PCR conditions applied for the detection of Florfenicol, $\beta$-lactams and Sulfonamides resistance genes among Salmonella isolates.

\begin{tabular}{cccc}
\hline \multirow{2}{*}{ Stage } & \multicolumn{3}{c}{ Temperature/Time } \\
\cline { 2 - 4 } & floR gene & bla TEM gene & Sul-1gene \\
\hline Initial denaturation & $95^{\circ} \mathrm{C} / 5 \mathrm{~min}$ & $94^{\circ} \mathrm{C} / 5 \mathrm{~min}$ & $94^{\circ} \mathrm{C} / 1 \mathrm{~min}$ \\
\hline Denaturation & $95^{\circ} \mathrm{C} / 45 \mathrm{~s}$ & $94^{\circ} \mathrm{C} / 30 \mathrm{~s}$ & $94^{\circ} \mathrm{C} / 1 \mathrm{~min}$ \\
\hline Annealing & $52^{\circ} \mathrm{C} / 45 \mathrm{~s}$ & $54^{\circ} \mathrm{C} / 30 \mathrm{~s}$ & $60^{\circ} \mathrm{C} / 1 \mathrm{~min}$ \\
\hline Extension & $72^{\circ} \mathrm{C} / 1 \mathrm{~min}$ & $72^{\circ} \mathrm{C} / 1 \mathrm{~min}$ & $72^{\circ} \mathrm{C} / 1 \mathrm{~min}$ \\
\hline Final extension & $72^{\circ} \mathrm{C} / 10 \mathrm{~min}$ & $72^{\circ} \mathrm{C} / 10 \mathrm{~min}$ & $72^{\circ} \mathrm{C} / 10 \mathrm{~min}$ \\
\hline
\end{tabular}

Molecular identification of Streptomycin resistance gene by multiplex PCR: 
Table 3: Presenting primers, its sequences and amplicon size (bp) for identification of streptomycin resistance gene among salmonella isolates.

\begin{tabular}{|c|c|c|c|c|c|}
\hline & Primers & Target & Primer sequence & $\begin{array}{l}\text { Amplicon } \\
\text { size }\end{array}$ & References \\
\hline \multirow{6}{*}{ 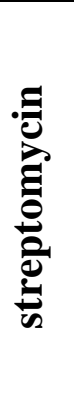 } & agdA_F & \multirow{3}{*}{$\operatorname{aadA}$} & GTGGATGGCGGCCTG & \multirow{3}{*}{$525 \mathrm{bp}$} & \multirow{3}{*}{$\begin{array}{c}\text { Madsen } \text { et al., } \\
2000\end{array}$} \\
\hline & & & AAGCC & & \\
\hline & aadA-R & & $\begin{array}{l}\text { AATGCCCAGTCGGCA } \\
\text { GCG }\end{array}$ & & \\
\hline & \multirow{2}{*}{ strA-strB-F } & \multirow{3}{*}{$\begin{array}{l}\text { strA- } \\
\text { strB }\end{array}$} & ATGGTGGACCCTAAA & \multirow{3}{*}{$891 b p$} & \multirow{3}{*}{$\begin{array}{c}\text { Tamang et al., } \\
2007\end{array}$} \\
\hline & & & ACTCT & & \\
\hline & strA-strB-R & & $\begin{array}{c}\text { CGTCTAGGATCGAGA } \\
\text { CAAAG }\end{array}$ & & \\
\hline
\end{tabular}

PCR reaction conditions consisted of a primary denaturation at $94^{\circ} \mathrm{C}$ for $4 \mathrm{~min}$, followed by 35 cycles of denaturation at $94^{\circ} \mathrm{C}$ for $45 \mathrm{~s}$, annealing at $60^{\circ} \mathrm{C}$ for $45 \mathrm{~s}$ and primary extension at $72^{\circ} \mathrm{C}$ for $45 \mathrm{~s}$, followed by a last extension at $72^{\circ} \mathrm{C}$ for 10minutes.

\section{RESULTS}

The overall incidence of Salmonella infection in ducks was 16.6\%. 36 suspected Salmonella isolates were undergoing serological identification according to Kauffman - White scheme gave 15 isolates were positive for Salmonella spp. with a percentage rate $(41.6 \%)$ and 21 gave negative for Salmonella spp. with a percentage rate (58.3\%). $14(93.3 \%)$ of isolates belonged to $S$. typhimurium and one (6.6) isolates belonged to $S$. infantis.

All fifteen Salmonella isolates were harbored invA gene and amplified at 284 bp fragments as shown in Fig. (1). Out of 15 invA gene positive Salmonella isolates, $1(6.6 \%)$ isolate was positive for $f l j B$ gene indicating Salmonella infantis. Out of 15 invA gene positive Salmonella isolates, $14(93.3 \%)$ isolates were positive for $R f b j$ and fliC genes indicating Salmonella typhimurium as shown in Fig. (2).
Antibacterial sensitivity test of Salmonella isolates using the disc diffusion technique:

All Salmonella isolates were completely sensitive $(100 \%)$ to amikacin, ciprofloxacin, enrofloxacin and Sulfamethoxazole/trimethoprim and they had a variable sensitivity to tetracycline and oxytetracycline (86.7\% of each), doxycycline and gentamicin $(80 \%$ of each), chloramphenicol and ampicillin (60\% of each) and colistin sulfate (20\%). they had intermediate sensitivity to neomycin (73.3\%), streptomycin (33.3\%), Ampicillin (13.3\%), and (6.7\%) for doxycycline and chloramphenicol. All isolates were completely resistance $(100 \%)$ to cephardine and amoxicillin, while they showed a variable degree of resistance to colistin sulfate $(80 \%)$, streptomycin (60\%), chloramphenicol (33.3\%), ampicillin and neomycin (26.7\% of each), gentamicin $(20 \%)$ and $(13.3 \%)$ for tetracycline, oxytetracycline and doxycycline as shown Fig. (3).

\section{Antibacterial sensitivity test of Salmonella isolates using MIC technique:}

All examined salmonella isolates were were absolutely sensitive to colistin and doxycycline, while they were completely resistant sulphaquinoxalin and highest 
rate of resistance was against cephradine, amoxicillin, streptomycin and florfenicol, but the lowest degree of resistance for gentamicin and neomycin.

\section{Detection of resistance genes in Salmonella isolates:}

All Salmonella isolates were positive (100\%) for Sul-1 gene (Sulfonamide resistance gene) which giving amplification at $316 \mathrm{bp}$ fragments as shown in Fig. (4). Eleven Salmonella isolates (11/15) $(73.3 \%)$ were positive for bla TEM gene ( $\beta$-lactams resistance gene) from the 15 examined Salmonella isolates which giving amplification at
517 bp fragments as shown in Fig. (4). Seven Salmonella isolates (7/15) (46.7\%) were positive for floR gene (florfenicol resistance gene) from the 15 examined Salmonella isolates which giving amplification at $888 \mathrm{bp}$ fragments as shown in Fig. (5). Eleven Salmonella isolates (11/15) (73.3\%) were positive for strA-strB (streptomycin resistance gene) while, Ten Salmonella isolates $(10 / 15)(66.7 \%)$ were positive for aadA gene (streptomycin resistance gene), from the 15 examined Salmonella isolates which giving amplification at $891 \mathrm{bp}$ and $525 \mathrm{bp}$ fragments as shown in Fig.(6).

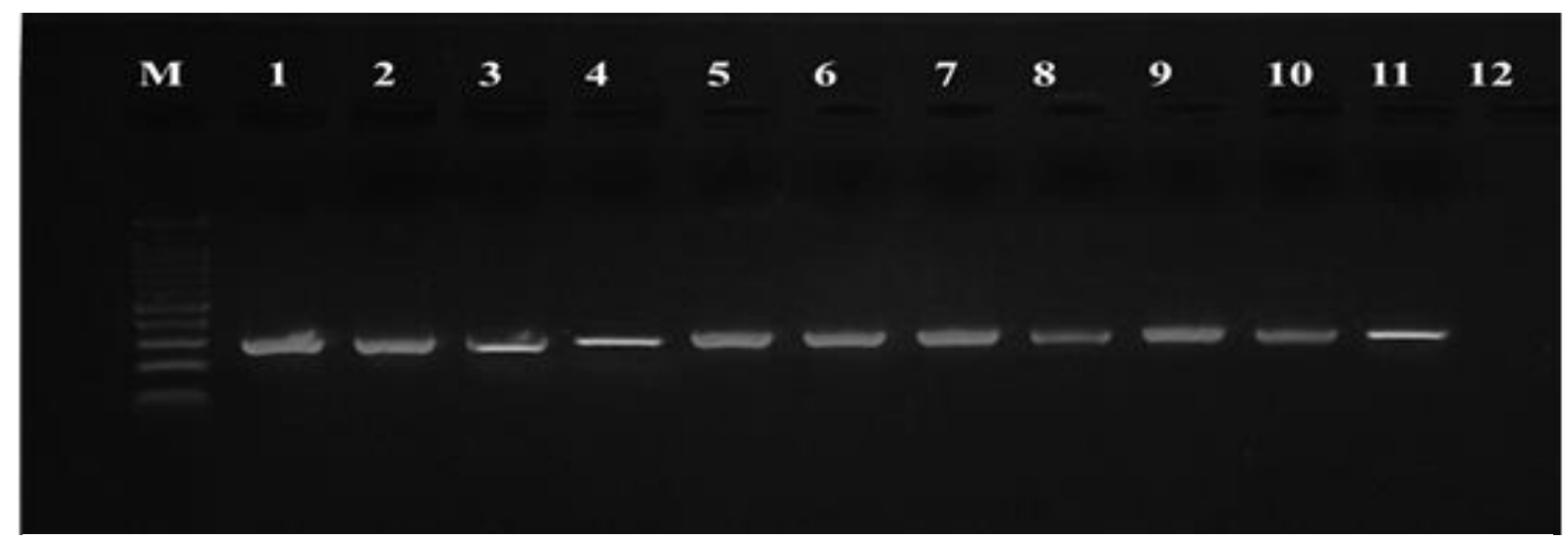

Fig. (1): Detection of invAgene in Salmonella isolates. Positive samples produce band (284 pb), Lane M: $1 \mathrm{~Kb}$ DNA Ladder, Lane: 1 to 11 were positive samples produce band (284 bp)

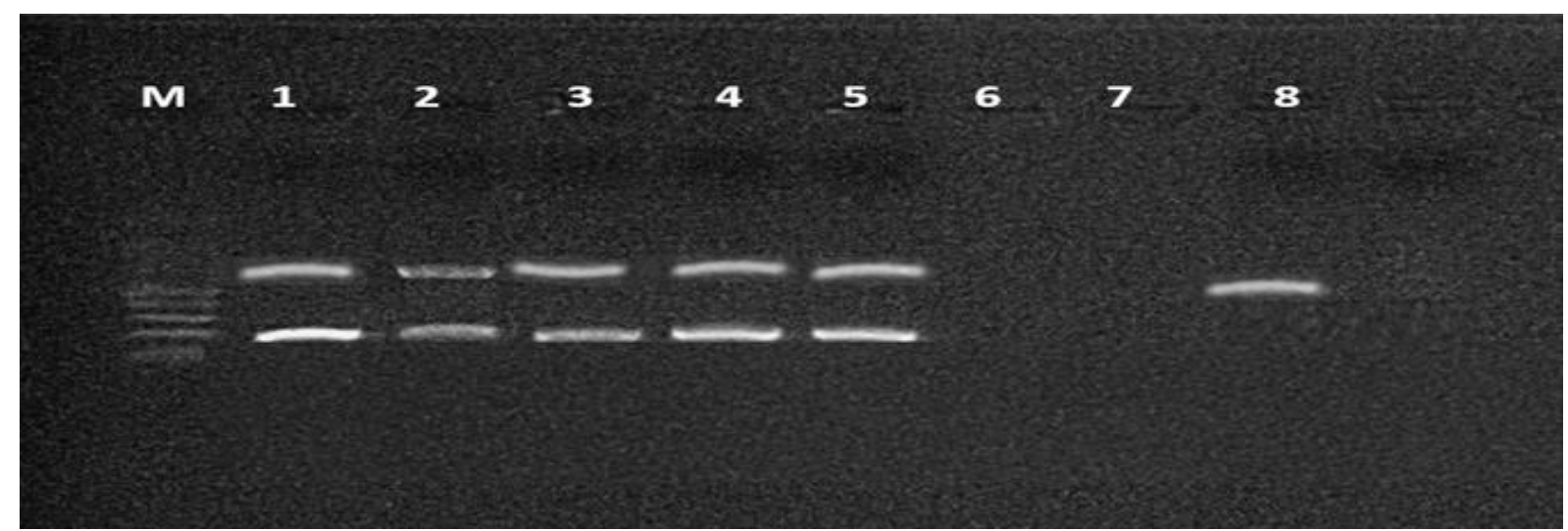

Fig. (2): Detection of $\boldsymbol{R} \boldsymbol{f b j}$ and $\mathbf{f l i C}$ genes specific for $S$. typhimurium and $\mathbf{f l j B}$ gene specific for $S$. infantis in samples. Positive samples produce bands (663 and 183bp) specific for $S$. typhimurium and (413 bp) specific for $S$. infantis. Lane M: $1 \mathrm{~Kb}$ DNA Ladder, Lane: (1 to 5) positive samples for S. typhimurium (produce bands 663 and 183bp) while, Lane: (8) positive samples for $S$. infantis produce band (413bp). 


\section{Antimicrobial sensitivity of Salmonella isolates}

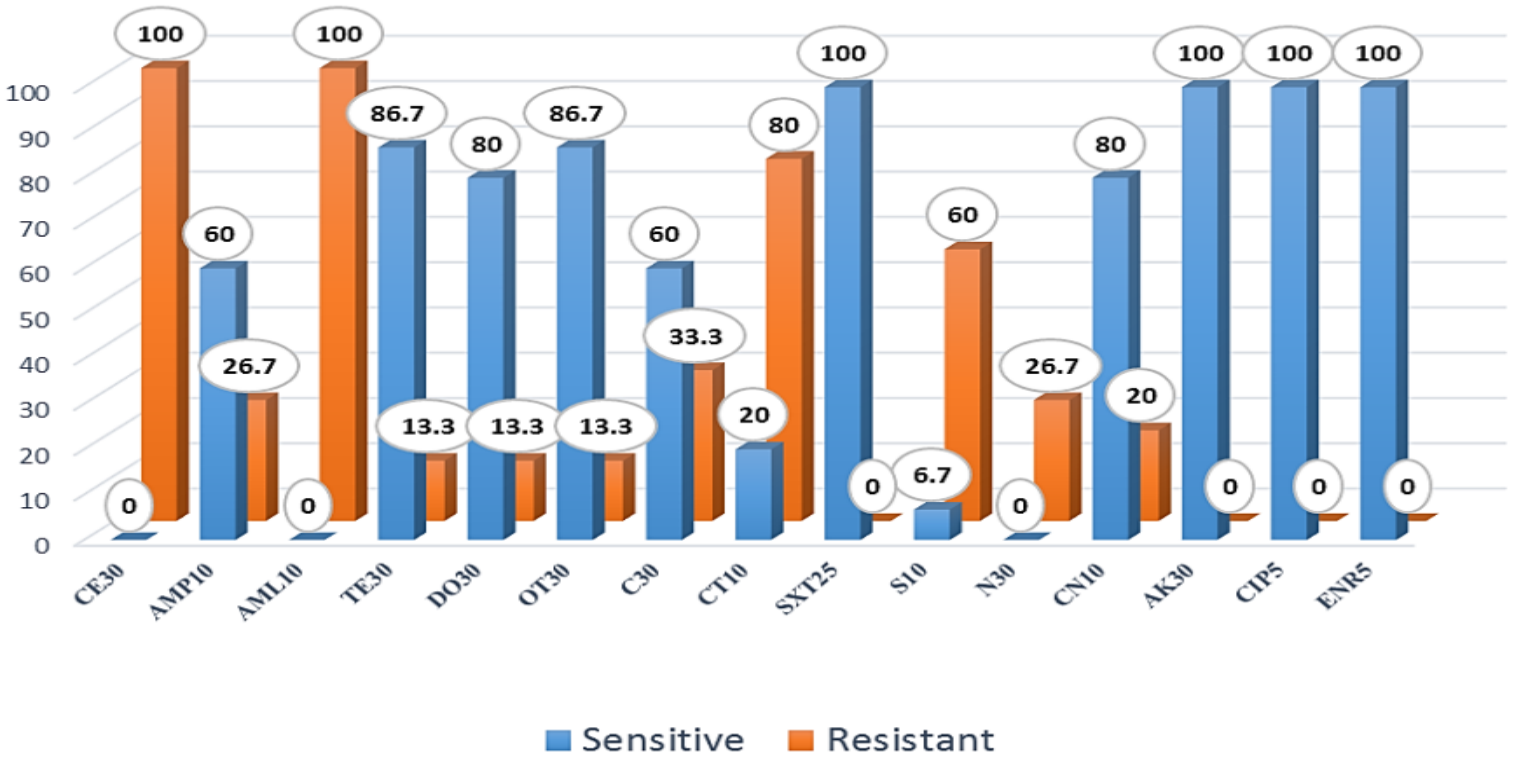

Fig. (3): antibacterial sensitivity and resistance percentages of isolated Salmonellae

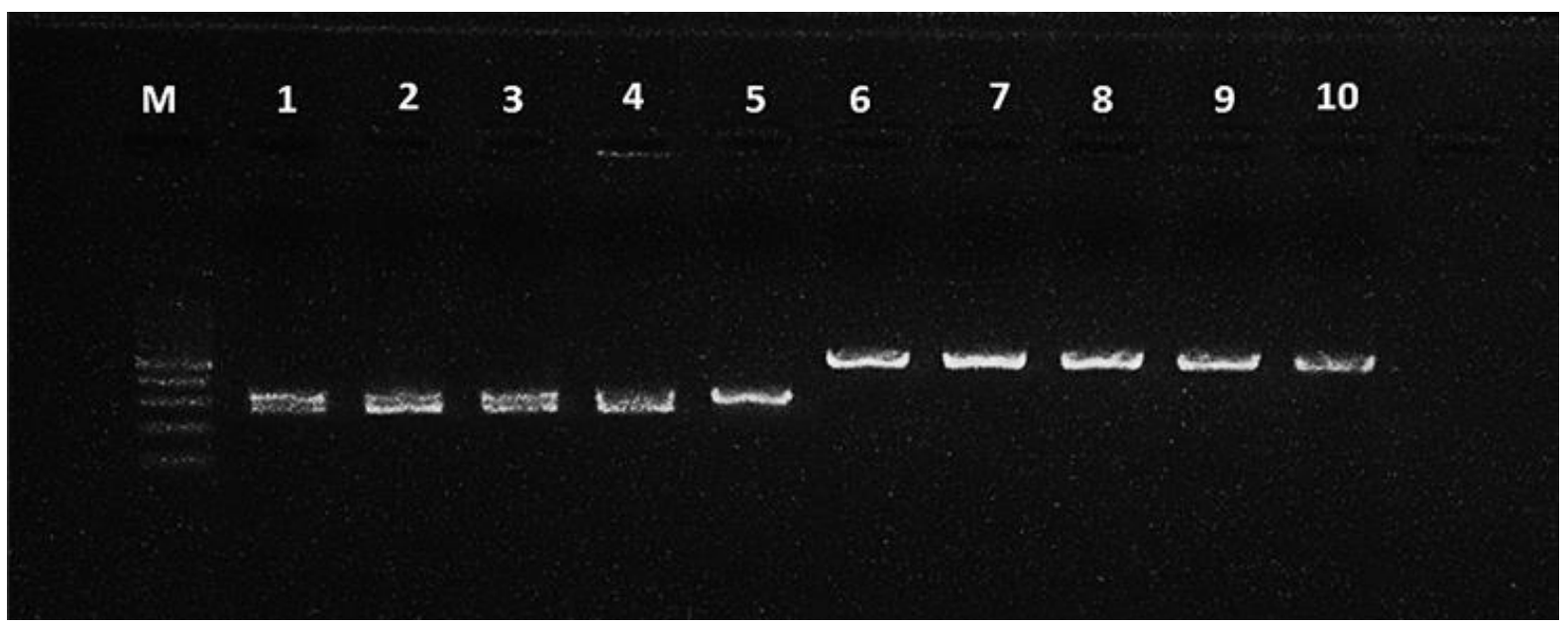

Fig. (4): Detection of Sul-1 and bla TEM gene in Salmonella isolates. Positive samples produce band (316 and 517bp), respectively. Lane M: $1 \mathrm{~Kb}$ DNA Ladder, Lane: 1, 2, 3, 4 and 5 were positive samples produce band (316bp) for Sul-1gene and Lane: 6,7,8,9 and 10 were positive samples produce band (517bp) for bla TEM gene. 


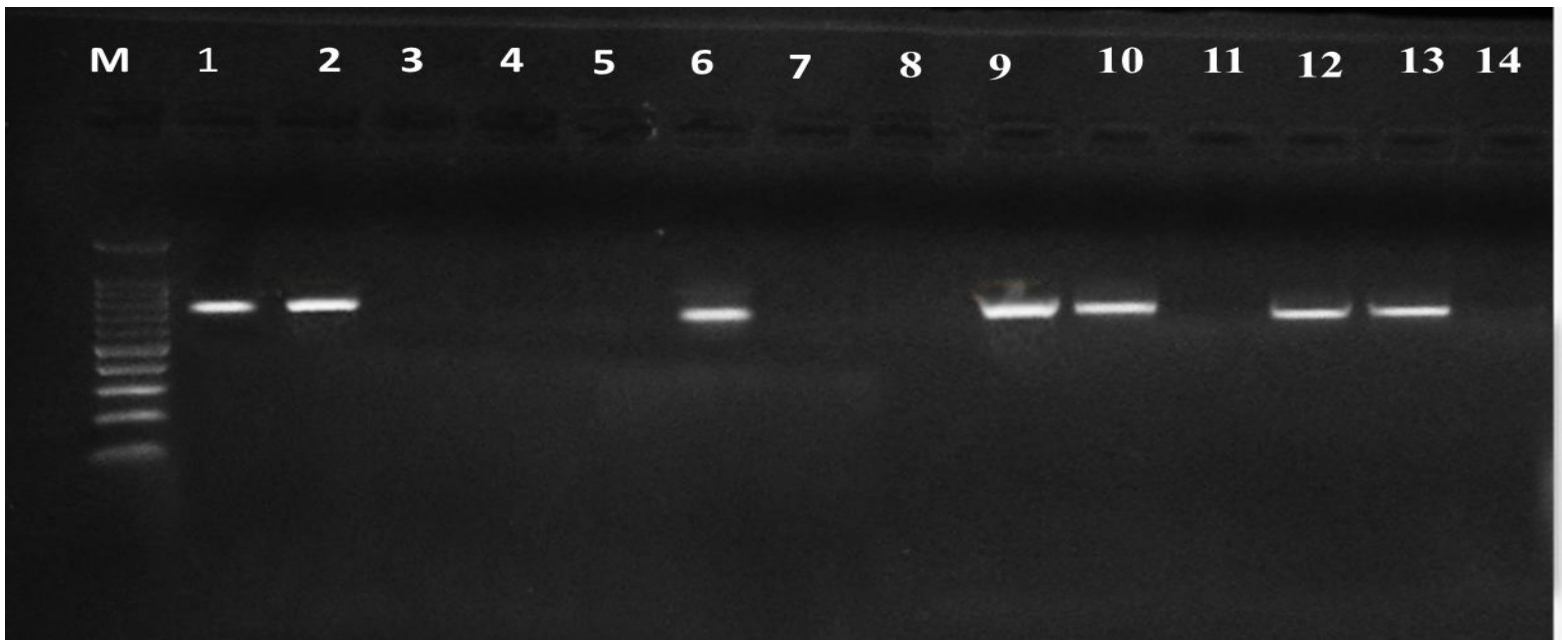

Fig. (5): Detection of floR gene in Salmonella isolates. Positive samples produce band (888pb), Lane M: $1 \mathrm{~Kb}$ DNA Ladder, Lane: 1, 2, 6,9,10,12 and 13 were positive samples produce band (888bp) while, Lane: 3,4,5,7,8,11 and 14 were negative samples.

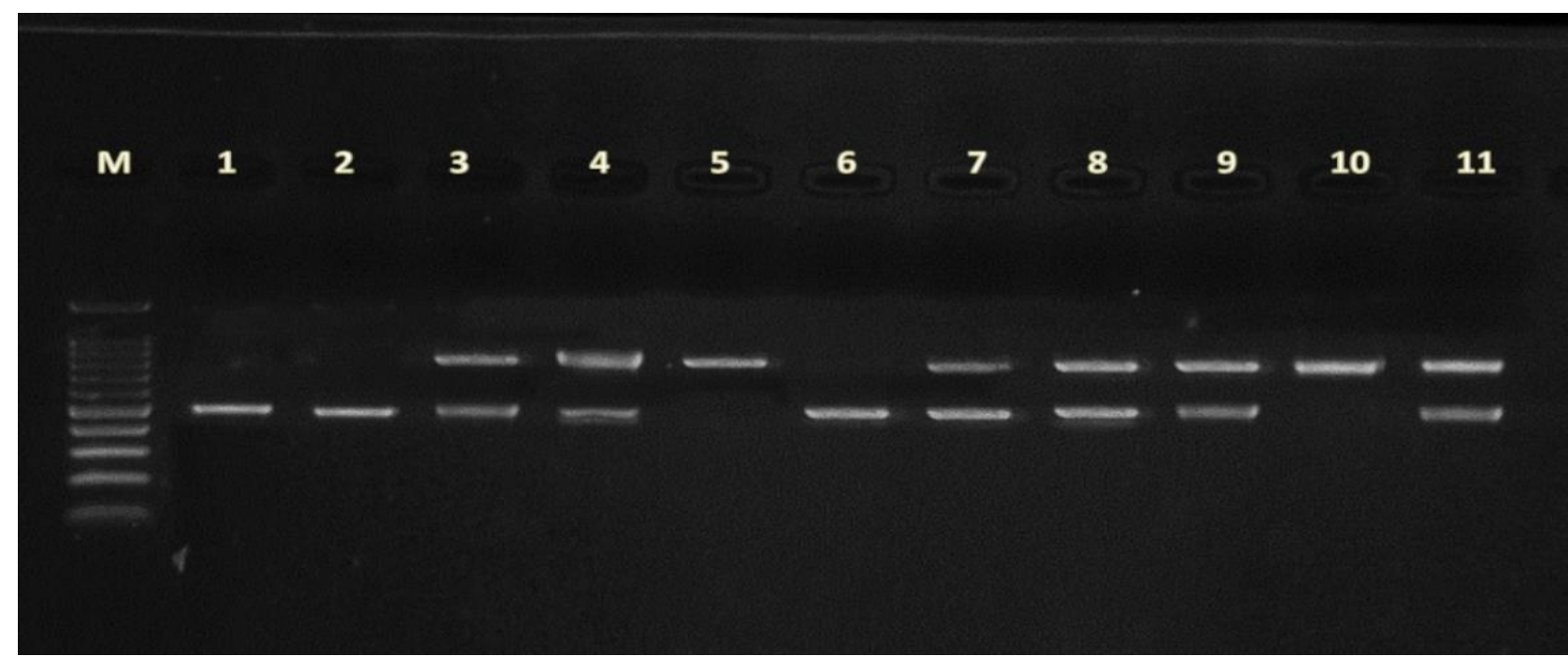

Fig. (6): Detection of $s t r A-s t r B$ and aadA genes in Salmonella isolates. positive samples produce bands (891 and 525bp) respectively, Lane $\mathbf{M}: 1 \mathrm{~Kb}$ DNA Ladder, Lane: $1,2,3,4,6,7,8,9,11$ were positive samples produce band of 525bp for aadA gene. while, Lane: $3,4,5,7,8,9,10,11$ were positive samples produce band $(891 \mathrm{bp})$ for strA-strB gene and lane: $3,4,7,8,9,11$ were positive samples produce 2 bands ( 891 and 525bp) for strA$s t r B$ and aadA genes, respectively.

Table 4: Distribution of resistance genes among Salmonella isolates with different serotypes.

\begin{tabular}{cccccc}
\hline \multirow{2}{*}{ Serotype (No.tested) } & \multicolumn{5}{c}{ No. of resistance genes positive isolates (\%) } \\
\cline { 2 - 6 } & Sul-1 & blaTEM & StrA-StrB & aadA & floR \\
\hline S.typhimurium(14) & $14(100)$ & $10(71.4)$ & $10(71.4)$ & $9(64.3)$ & $7(50 \%)$ \\
\hline S.infantis (1) & $1(100)$ & $1(100)$ & $1(100)$ & $1(100)$ & - \\
\hline Total examined (15) & $15(100)$ & $11(73.3)$ & $11(73.3)$ & $10(66.7)$ & $11(46.7)$ \\
\hline
\end{tabular}

Sul-1= resistant gene for sulfonamide.

Bla $\mathbf{T E M}=$ resistant genes for $\beta$-lactams

$\boldsymbol{F l o R}=$ resistant gene for florfenicol.

$\operatorname{aad} \mathrm{A}$ and $\boldsymbol{s t r} \mathbf{A}-\mathbf{s t r} \boldsymbol{B}=$ resistant gene for streptomycin. 


\section{DISCUSSION}

Pathogenic Salmonella isolates in ducklings and duck farms can be identified using Polymerase Chain Reaction (PCR) (Yang et al., 2019). The invasion gene (invA) encodes a protein found in bacteria's inner membrane that is required for invasion of the host's intestinal mucosa (Singh et al., 2013) and a common unique marker gene in all isolates of Salmonella species (Liu et al., 2012). In this study, The PCR confirmed the conventional tests performed and all 15 examined isolates were positive for invA gene with $100 \%$ specificity, the size of amplified product was 284 bp as shown in Fig. (1). similar findings have been described by (Elgohary et al., 2017) who detected invA genes in all Salmonella serovars isolated from duck farms.

Fourteen salmonella isolates (93.3\%) were positive for $R f b j$ and $f l i C$ genes indicating $S$. typhimurium and one (6.7\%) was positive for $f l j B$ gene indicating $S$. infantis as shown in Fig. (2). The predominant serotype in this study was $S$. typhimurium in duck farms. These results went in parallel with these reported by (Niu et al., 2020) who found that $S$. typhimurium was the common serotype recovered from ducks in China, (Abel-Tawab et al., 2020 and El shabrawy et al., 2021) who reported that $S$. typhimurium was the predominant isolated from ducks in Egypt these results in contrast to (Enany et al., 2018) who found that $S$. ruzizi, S. give and $S$. entertidis isolated from local duckling with $0.5 \%$ for each. (Han et al., 2020) who found that S. Indiana $(26.3 \%)$ as one of the prevalent serovars in duck carcasses from China. The $2^{\text {nd }}$ common serotype in this study was $S$. infantis $(6.7 \%)$ and detected in high percentage
(14.6\%) in retail duck meat in China by (Chen et al., 2020). This was due to the fact that the distribution of the most common Salmonella serotypes is largely determined by geographical factors that change over time (Huehn et al., 2010), and may be related to sampling methods and isolation techniques (Vanantwerpen et al., 2016), despite the fact that several serotypes are consistently detected at a high rate around the world (Gast, 2007).

According to the results concerning antimicrobial susceptibility test presented in Fig. (3). Fifteen salmonella isolates showed the highest percentage of resistance $(100 \%)$ to cephradine and amoxicillin followed by colistin sulfate (80\%), streptomycin (60\%) and chloramphenicol (33.3\%). These findings were higher than those reported by (Abouzeid et al., 2020) who documented that amoxicillin/clavulanic resistance was $70 \%$ in Salmonella isolated from diarrheic ducklings. In contrary to these results (Abd El-Tawab et al., 2018) who found that salmonella isolated from laying ducks were sensitive to amoxicillin and streptomycin. This was associated to excessive use of these antibacterial agents in duck farms as result of the increased rates of duck diseases due to the development of intensive animal husbandry and high stocking density (Guo et al., 2020).

In this work, all Salmonella isolates were $100 \%$ sensitive to amikacin, ciprofloxacin, enrofloxacin and trimethoprim/ sulphamethoxazole, followed by tetracycline $(86.7 \%)$, gentamicin (80\%), ampicillin and chloramphenicol (60\% for each). These results to some extent agree with (Abouzeid et al., 2020) who reported that salmonella isolates were amikacin 
sensitive by 100\%, followed by gentamicin and sulphamethoxazole/ trimethoprim $(50 \%$ for each). In contrary to these results (El-shabrawy et al., 2021) who found that salmonella isolates displayed high resistance rate to tetracycline (85\%), amikacin and sulphamethoxazole/ trimethoprim $(62.8 \%$ for each) and ampicillin $(51.4 \%)$.

In this study, antibacterial sensitivity test by using MIC showed that all examined salmonella isolates were absolutely sensitive to colistin and doxycycline, while the highest rate of resistance was against sulfaquinoxalin, cephradine, amoxicillin and florfenicol, while variable degree of resistance for streptomycin, gentamicin and neomycin. these findings nearly in agreement with (Chen et al., 2020) who reported that the highest levels of resistance were observed for sulfadiazine, followed by florfenicol, streptomycin, and gentamicin. These findings differed with (Zhao et al., 2017) stated that most 56 isolates recovered from ducks were resistant to tetracycline, ampicillin and ciprofloxacin.

In this study, all fifteen Salmonella isolates $(100 \%)$ were resistant to at least two antibacterial agents, while $93.3 \%$ $(14 / 15)$ of the examined isolates exhibited Multidrug resistant (MDR) were resistant to 3or more antibacterial agents and Resistance to 3-8 antibacterial agents was detected in 12 isolates $(80 \%), 2$ isolates $(14.3 \%)$ were resistant to 9-11 antibacterial agents. These results were higher than (Chen et al., 2020) investigated that $133(88.1 \%)$ of salmonella isolates exhibited MDR, (Han et al., 2020) who found that $63.5 \%$ of Salmonella isolates were classified as
MDR which were resistant to 3 or more antimicrobial agents.

PCR was a perfect tool for perfect detection of Salmonella resistant genes and the results that the sul-lgene, a gene encoded for sulfonamide resistance was reported in the present study with a percentage of $100 \%$ among Salmonella isolates as shown in Fig. (4). these results consistently, (Niu et al., 2020) who detected sul-1 gene in 92 salmonella isolates isolated from duck farms in south China was $97.8 \%$, these results were higher than results obtained by (Chen et al., 2020) who found that sul-1 gene with percentage of $63 \%$ and (Abd El-Tawab et al., 2015) who reported that Sul-1with percentage of $87 \%$.

The bla TEM gene, a gene encoded for $\beta$-lactamases resistance was reported in the present study with a percentage of $73.3 \%$ (11 out of 15 isolates) which giving amplification at $517 \mathrm{bp}$ fragments as shown in Fig. (4). These results were higher than (Abdallah et al., 2015) who reported that bla TEM gene with percentage of $41.2 \%$ and (Zhao et al., 2017) who reported that bla TEM gene with percentage of $35.7 \%$ among 56 isolates recovered from ducks.

The floR gene, a gene encoded for florphenicol resistance was reported in the present study with a percentage of $46.7 \%$ (7 out of 15 isolates) which giving amplification at 888 bp fragments as shown in Fig. (5). These results were higher than results obtained by (Zhao et al., 2017) who reported that floR gene with percentage of $23.2 \%$ among 56 isolates recovered from ducks. These results were lower than results obtained by (Abd El-Tawab et 
al., 2015) who reported that floR gene with percentage of $77.8 \%$ and (Niu et al., 2020) who detected flo $\mathrm{R}$ in 92 salmonella isolates obtained from duck farms in south China was $97.8 \%$.

The StrA-strB and aadA genes, genes encoded for streptomycin resistance were reported with a percentage of (11 out of 15 isolates) $73.3 \%$ and (10 out of 15 isolates) $66.7 \%$, respectively as shown in Fig. (6) these results were lower than results obtained by (Niu et al., 2020) who detected aadAl in 92 salmonella isolates obtained from duck farms in south China was $100 \%$, (Chen et al., 2020) who documented that StrA gene and aadAl with percentage of $94.1 \%$ and $83.8 \%$, respectively while these results were higher than (Abd ElTawab et al., 2015) who reported that aadA2 gene with percentage of $53.1 \%$, (Abdallah et al., 2015) who reported that $\operatorname{aadA2}$ gene with percentage of $47 \%$. The detection rates of resistant genes greatly differ among diverse studies due to the various circumstances and dosages of antibiotics used in the farms (Niu et al., 2020) and as result of the excessive number of related genes that mediate resistance to these antibacterial agents or alternatively, due to changes in the Salmonella resistance mechanism result from geographical or other factors (Chen et al., 2020).

\section{REFERENCES}

Abdallah, E.F.; Nasef, S.A.; El-Hariri, M. and Refai, M. (2015): Genotypic characterization of antibiotic resistant Salmonella isolates recovered from local and imported poultry. Journal of Global Biosciences, 4(6): 26112622.
Abd El-Tawab, A.A.; El-Hofy, F.I.; Ammar, A.M.; Nasef, S.A. and Nabil, N.M. (2015): Molecular studies on antimicrobial resistance genes in salmonella isolated from poultry flocks in Egypt. Benha veterinary medical journal, 28(2): 176-187.

Abd El-Tawab, A.A.; El-Nahas, E.M.; Askora, A.A. and Abdelaziz, H.S. (2018): Bacteriological characterization of Salmonella species isolated from laying ducks. Benha veterinary medical journal, 34(1): 404-412.

Abd El-Tawab, A.A.; Maarouf, A.A.A.; Elhofy, F.I. and Abd El- Ghaffar, I.M.S. (2020): Bacteriological and molecular studies on Salmonella isolated from duckling farms at Kaliobia, Egypt. Benha veterinary medical journal, 39(1): 169-174.

Ahmed, A.M.; Hussein, A.I.A. and Shimamoto, T. (2007): Proteus mirabilis clinical isolate harbouring a new variant of Salmonella genomic island 1 containing the multiple antibiotic resistance region. Journal of Antimicrobial Chemotherapy, 59(2): 184-190.

Abou Zeid, M.A.M.; Nasef, S.A.; Ali, G.I.E. and Hegazy, A.M. (2020): A Field Study on Biochemical Changes Associated with Salmonella Infection in Ducklings. Journal of World's Poultry Research, 10(2S): 250-262.

Buxton, A. (1957): Salmonellosis in Animals. A Review Series No. 5 of the Commonwealth Bureau of Animal Health. Commonwealth Agricultural Bureaux, Farham Royal. Bucks, England, 50: 1.

Chen, Z.; Bai, J.; Wang, S.; Zhang, X.; Zhan, Z.; Shen, H.; Liao, $M$. (2020): Prevalence, antimicrobial 
resistance, virulence genes and genetic diversity of Salmonella isolated from retail duck meat in southern China. Microorganisms, 8(3): 444.

Clinical and Laboratory Standards Institute (CLSI) (2018): Performance Standards for Antimicrobial Disk Susceptibility Tests, M100S, 28 ${ }^{\text {th }}$ Ed., CLSI Vol.-38No.3.

Colom, K.; Pérez, J.; Alonso, R.; Fernández-Aranguiz, A.; Lariño, E. and Cisterna, R. (2003): Simple and reliable multiplex PCR assay for detection of bla TEM, bla SHV and bla OXA-1 genes in Enterobacteriaceae. FEMS microbiology letters, 223(2): 147151.

Dashti, A.A.; Jadaon, M.M.; Abdulsamad, A.M. and Dashti, H.M. (2009): Heat treatment of bacteria: a simple method of DNA extraction for molecular techniques. Kuwait Medical Journal, 41(2): 117-122.

Elgohary, A.H.; AbuElnaga, A.S.M.; Ibrahim, H.S.; Hedia, R.H.; Dorgham, S.M. and Elgabry, E.A. (2017): Detection of virulence genes of Salmonella in diarrhoeic ducks by using Polymerase chain reaction (PCR). Egyptian Journal of Veterinary Sciences, 48(1): 1121.

Enany, M.E.; Wafaa, M.M. and Reem, M.M. (2018): Comparison between different methods for detection of Salmonella species in imported and local duckling. Suez Canal Veterinary Medical Journal., 23(1): 171-180.

El-shebrawy, H.A.; Mahros, M.M.; AbdElghany, S.M.; Elgazzar, M.M.; Hayashidani, H. and Sallam, K.I. (2021): Prevalence and molecular characterization of multidrug resistant and $\beta$-lactamase producing Salmonella enterica serovars isolated from duck, pigeon, and quail carcasses in Mansoura, Egypt. LWT-Food Science and Technology, 149: 111834.

Gast, R.K. (2007): Serotype-specific and serotype-independent strategies for preharvest control of food-borne Salmonella in poultry. Avian diseases, 51(4): 817-828.

Gast, R.K. (2008): Paratyphoid infections. In: Diseases of poultry, Saif, Y. M. ; Fadly, A. M. ; Glisson, J. R. ; McDougald, L. R. ; Nalon, L. K. ; Swayne, D. E. 12th ed. Iowa State University Press, Ames. 636-665.

Guo, Y.; Zhao, Z.H.; Pan, Z.Y.; An, L.L.; Balasubramanian, $B$. and Liu, W.C. (2020): New insights into the role of dietary marinederived polysaccharides on productive performance, egg quality, antioxidant capacity, and jejunal morphology in late-phase laying hens. Poultry science, 99(4): 2100-2107.

Han, X.; Peng, J.; Guan, X.; Li, J.; Huang, X.; Liu, S. and Zou, L. (2020): Genetic and antimicrobial resistance profiles of Salmonella spp. isolated from ducks along the slaughter line in southwestern China. Food Control, 107: 106805.

Huehn, S.; La Ragione, R.M.; Anjum, M.; Saunders, M.; Woodward, M.J.; Bunge, C. and Beutlich, J. (2010): Virulotyping and antimicrobial resistance typing of Salmonella enterica serovars relevant to human health in Europe. Foodborne pathogens and disease, 7(5): 523-535. 
ISO 6579 (2002): Microbiology of food and animal feeding stuffshorizontal method for the detection of salmonella species. International standard. $\quad\left(4^{\text {th }}\right.$ edition).

Jamshidi, A.; Bassami, M. and AfshariNic, S. (2009): Identification of salmonella species and Salmonella typhimurium by a multiplex PCR based assay from poultry carcasses in Mashhad- Iran. Int. J. Vet. Res. 3: 43-48.

Kardos, G.; Farkas, T.; Antal, M.; Nógrády, N. and Kiss, I. (2007): Novel PCR assay for identification of Salmonella enterica serovar infantis. Letters in Applied Microbiology 45, 421-425.

Lim, Y.; Hirose, K.; Izumiya, $H_{\text {.; }}$; Arakawa, E.; Takahashi, H.; Terajima, $J$. and Watanabe, $H$. (2003): Multiplex polymerase chain reaction assay for selective detection of Salmonella enterica serovar typhimurium. Japanese journal of infectious diseases, 56(4): 151-155.

Madsen, L.; Aarestrup, F.M. and Olsen, J.E. (2000): Characterisation of streptomycin resistance determinants in Danish isolates of Salmonella typhimurium. Veterinary microbiology, 75(1): 73-82.

McEwen, S.A. (2012): Human health importance of use of antimicrobials in animals and its selection of antimicrobial resistance. Antimicrobial

Resistance In The Environment. Canada: Wiley-Blackwell, 391423.

Niu, J.L.; Peng, J.J.; Ming, Y.Y.; Ma, Q.C.; Liu, W.C. and Ma, Y. (2020): Identification of drug resistance genes and drug resistance analysis of Salmonella in the duck farm environment of Zhanjiang, China. Environmental Science and Pollution Research, 27(20): 24999-25008.

Oliveira, S.D.; Santos, L.R.; Schuch, D.M.T.; Silva, A.B.; Salle, C.T.P. and Canal, C.W. (2002): Detection and identification of salmonellas from poultry-related samples by PCR. Veterinary microbiology, 87(1): 25-35.

Randall, L.P.; Cooles, S.W.; Osborn, M.K.; Piddock, L.J.V. and Woodward, M.J. (2004): Antibiotic resistance genes, integrons and multiple antibiotic resistance in thirty- five serotypes of Salmonella enterica isolated from humans and animals in the UK. Journal of Antimicrobial Chemotherapy. 53: 208- 216.

Santos, L.R.; Nascimento, V.P.; Oliveira, S.D.; Flores, M.L.; Pontes, A.P.; Ribeiro, A.R.; Salle, C.T.P. and Lopes, R.F.F. (2001): Polymerase chain reaction (PCR) for the detection of Salmonella in artificially inoculated chicken meat, Review Inst. Medicine trop. S. Paulo, 43 (5):247-250.

Singh, S.; Singh, H.; Tewari, S.C.; Nambiar, P. and Agarwal, R.K. (2013): Characterization of virulence factors among diverse Salmonella serotypes and sources. Advances in Animal and Veterinary Sciences, 1(2): 69-74.

Stanković, M.S.; Radić, Z.S.; BlancoSalas, J.; Vázquez-Pardo, F.M. and Ruiz-Téllez, T. (2017): Screening of selected species from Spanish flora as a source of bioactive substances. Industrial crops and products, 95: 493-501. 
Tamang, M.D.; Oh, J.Y.; Seol, S.Y.; Kang, H.Y.; Lee, J.C.; Lee, Y.C. and Kim, J. (2007): Emergence of multidrug-resistant Salmonella enterica serovar typhi associated with a class 1 integron carrying the dfrA7 gene cassette in Nepal. International journal of antimicrobial agents, 30(4): 330335.

Vanantwerpen, G.; De Zutter, L.; Berkvens, D. and Houf, K. (2016): Impact of the sampling method and chilling on the Salmonella recovery from pig carcasses. International journal of food microbiology, 232: 22-25.
Yang, J.; Ju, Z.; Yang, Y.; Zhao, X.; Jiang, Z. and Sun, S. (2019): Serotype, antimicrobial susceptibility and genotype profiles of Salmonella isolated from duck farms and a slaughterhouse in Shandong province, China. BMC microbiology, 19(1): 1-12.

Zhao, X.; Yang, J.; Zhang, B.; Sun, S. and Chang, W. (2017): Characterization of integrons and resistance genes in Salmonella isolates from farm animals in Shandong province, China. Frontiers in microbiology, 8: 1300. 
التوصيف الجزيئى للجينات المقاومة للمضادات البكتيرية للسالمونيلا فى البط

زينب خليفة مصطفى ظليفة ، عوض عبد الحافظ إبراهيم ، طلبة بيونس عبد المطلب ، أزهار محمد عبل العزيز

E-mail: vet.zeinab@gmail.com. Assiut University web-site: www.aun.edu.eg

نتيجة للخسائر الإقتصادية الناجمة عن محاولة التغلب على الإصابة بالسالمونيلا فى الدواجن و التكاليف الباهظة

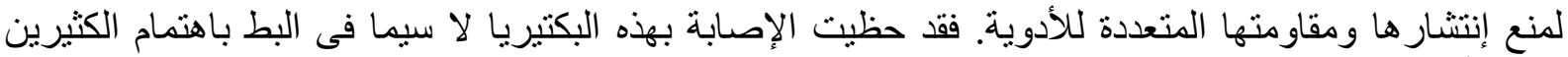

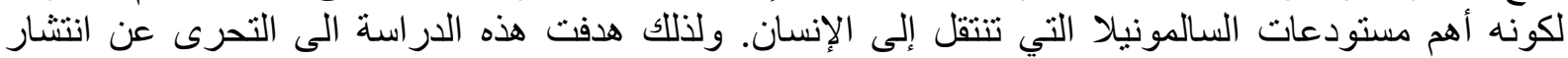

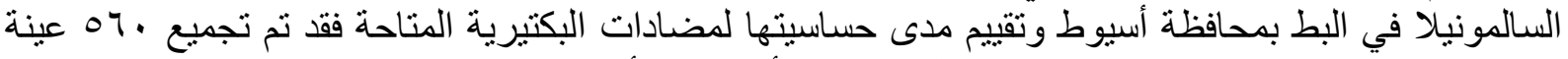

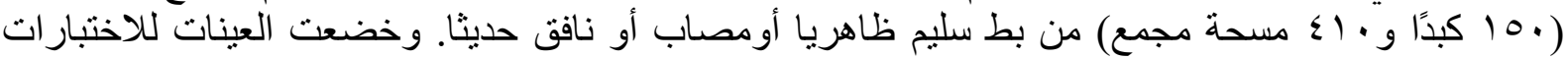

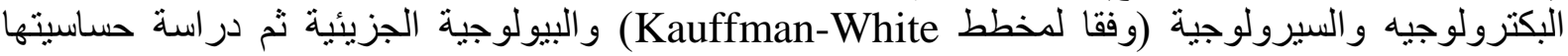

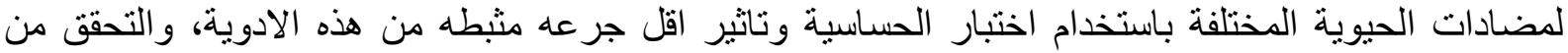
الجينات المسئولة عن مقاومة المضادات الحيوية جينيا باستخدام تفاعل البلمرة المتسلسل.

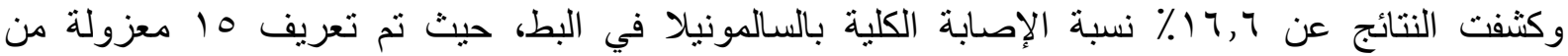

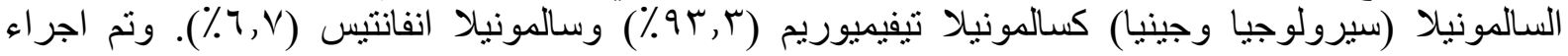

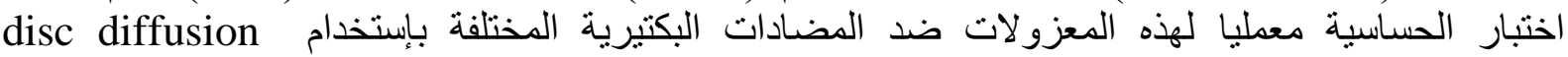

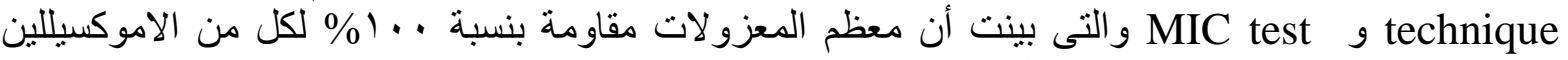

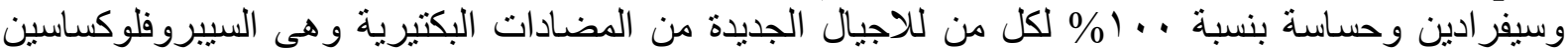

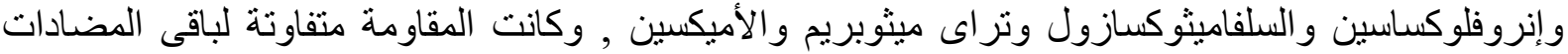

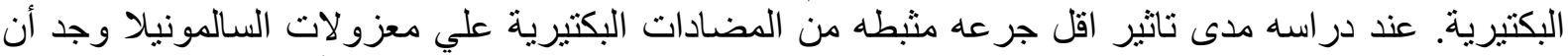

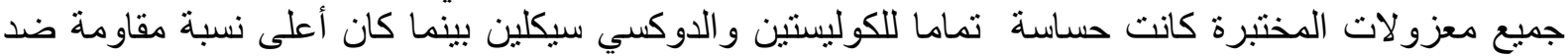

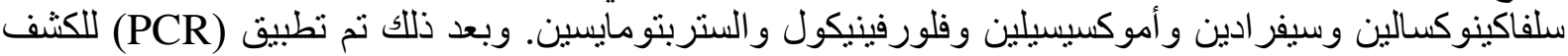

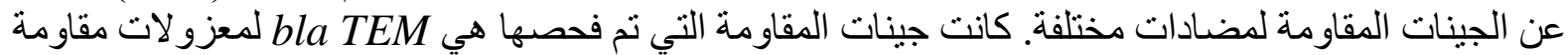

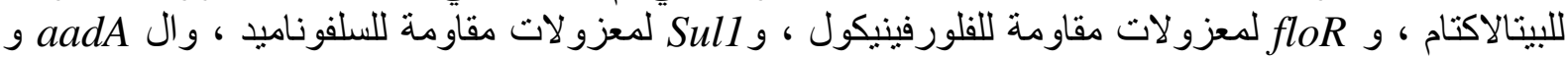
StrA- StraB

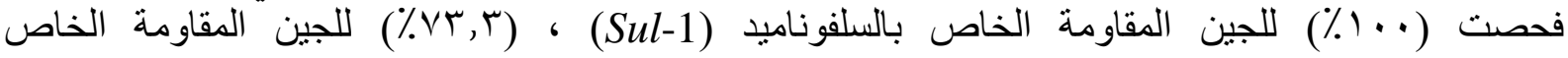

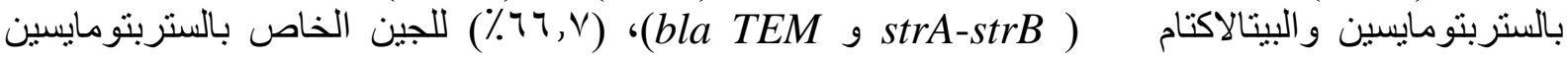

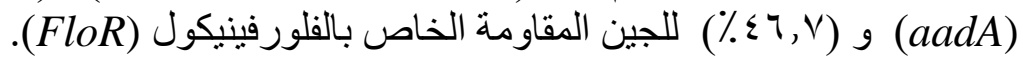

